\title{
Investigation on Potential Efficacy of Methanol Extract of Lawsonia inermis L. Against Carbon Tetrachloride Induced Hepatotoxicity in Wistar Albino Rats
}

\author{
A. Natarajan', R.Thangamani ${ }^{2}$, R. Prabakarakrishnan ${ }^{3}$, A. A. Ramanan ${ }^{4}$, A. Jayavelu ${ }^{\text {* }}$ \\ ${ }^{1}$ Department of Biochemistry, King Nandhivarman College of Arts \& Science, Thellar -604 406, Tamil Nadu, India. \\ ${ }^{2}$ Department of Zoology, Thiruvalluvar University, Serkkadu, Vellore-632 115, Tamil Nadu, India. \\ ${ }^{3}$ Department of Chemistry, Sri Chandrasekharendra Saraswathi Viswa Mahavidyalaya, Enathur, Kanchipuram, Tamil Nadu, India. \\ ${ }^{4}$ Centre for Ocean research, Sathyabama University, Semmancheri, Chennai -600119, Tamil Nadu, India. \\ 5PG Assistant in Biology, Government Higher Secondary School, Sainapuram -631051, Ranipet District, Tamil Nadu, India.
}

*Corresponding author's E-mail: jayaveluakkari358@gmail.com

Received: 18-06-2021; Revised: 24-08-2021; Accepted: 05-09-2021; Published on: 15-09-2021. \begin{abstract}
Carbon tetrachloride $\left(\mathrm{CCl}_{4}\right)$ a pharmacological tool was used to induce liver damage in Wistar albino rats. Silymarin $(100 \mathrm{mg} / \mathrm{kg})$ and methanol extract of Lawsonia inermis Linn. family Lythraceae (known to possess hepatoprotective compounds) was used to reverse the liver damage caused due to $\mathrm{CCl}_{4}$ (induced toxicity). Hydroalcholic extract of stem bark and leaf of Lawsonia inermis Linn. was evaluated, for its restorative efficacy against $\mathrm{CCl}_{4}$ induced hepatotoxicity which was assessed in terms of biochemical and histopathological parameters. $\mathrm{CCl}_{4}$ produce the altitude levels of serum marker enzymes of alanine aminotransferase (ALT), asparate aminotransferase (AST), alanine phosphatase (ALP) and bilirubin in blood serum. Due to the toxicity of $\mathrm{CCl}_{4}$ cause turbine hepatic cell architecture, necrosis, inflammatory cell infiltration, congestion, and sinusoidal dilatation along with reduction of superoxide dismutase (SOD), catalase, Glutathione-S-transferase (GST) and glutathione peroxidase (GPX) appeared in liver tissue. SOD is the primary step in the defense mechanism involved in the antioxidant system against the oxidative stress. It diminishes by converting the superoxide radical in to peroxide and molecular oxygen. CAT or GPx reactions, also exert a similar effect thereby reducing the level of cellular damage. By oral administration of methanol extract of Lawsonia inermis Linn. plant extracts, i.e., stem bark extract ( $250 \mathrm{mg} / \mathrm{kg}$ b.wt.) and leaf extract ( $250 \mathrm{mg} / \mathrm{kg} \mathrm{b.} \mathrm{wt.)} \mathrm{the} \mathrm{levels} \mathrm{of} \mathrm{these} \mathrm{parameters} \mathrm{was} \mathrm{restored} \mathrm{to} \mathrm{near} \mathrm{controlled} \mathrm{(untreated)}$ levels. Thus, the present study revealed that the extracts of stem bark and leaf of Lawsonia inermis Linn. offered protection against hepatotoxicity induced by $\mathrm{CCl}_{4}$.
\end{abstract}

Keywords: Lawsonia inermis, Liver marker enzymes, Carbon tetrachloride, Hepatoprotective.

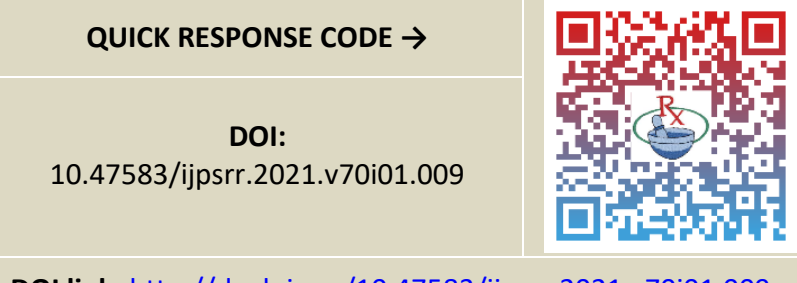

DOI link: http://dx.doi.org/10.47583/ijpsrr.2021.v70i01.009

\section{INTRODUCTION}

$\mathrm{H}$ epatic system is a very vital organ system involved in the body's metabolic and biochemical activities. Due to this, the chemical reactions in the liver may produce several reactive species like free radicals. These reactive species form strong bonds with the lipids of the tissue. However, some species do not built protective mechanisms oppose the hazardous reactions associated with the free radicals. Due to over exposure to toxic chemicals, the formation of free radicals will be so high that they overpower the natural defense system induce hepatic damage and cause jaundice, cirrhosis, fatty liver and abnormal architecture of the hepatic cells, which remain one of the serious health problems. Carbon tetrachloride $\left(\mathrm{CCl}_{4}\right)$ is one such hazardous chemical which induces hepatotoxicity through membrane lipid peroxidation by its free radical derivatives, trichloromethyl radical $\left(\mathrm{CCl}_{3}\right)$ and trichloromethylperoxy radical $\left(\mathrm{CCl}_{3} \mathrm{O}_{2}\right)$. Excessive production of the reactive species manifests in tissue thiol depletion, lipid peroxidation, plasma membrane damage etc., culminating in severe hepatic injury ${ }^{1-2}$. This can be controlled by the traditional systems of herbal medicine continue to play a vital role in the health care system of the population. ${ }^{3-4}$ Lawsonia inermis Linn. is regularly used by the rural and tribal people in curing various health disorders. ${ }^{5}$

Many of the antitumour drugs generate free radicals; they are known to produce myelosupression, nephrotoxicity and hepatotoxicity. ${ }^{6}$ Lawsonia interims Linn. was used for treatment of cancer. ${ }^{7}$ Besides its use in cosmetics for staining hands and producing hair dye, the leaves are used as a prophylactic against skin diseases. ${ }^{8}$ Lawsonia inermis Linn. is reported to have anti-inflammatory, antipyretic and analgesics properties. ${ }^{9-10}$ The bark extract of this plant is an appetiser, anti-inflammatory, used in liver disorders, fractures and also reported to be useful in jaundice, splenomegaly, ${ }^{10-13}$ calculus affliction, and skin diseases. ${ }^{14}$ The leaf extract of Lawsonia inermis has been shown to possess antimicrobial ${ }^{15}$ and antitubercular activity. Ethanol extract of the whole plant was found to have antifungal activity. ${ }^{16}$ An ointment prepared from the leaves was used to cure ulcers and wounds. ${ }^{17}$ The decoction of bark and 
leaves has been found to inhibit the peptic enzymes. ${ }^{18}$ The methanol extract of bark was found to alleviate the levels of liver marker enzymes and restore normal bile flow. ${ }^{19}$ $\mathrm{CCl}_{4}$ induced hepatotoxicity depends on the reductive dehalogenation of $\mathrm{CCl}_{4}$ catalyzed by Cyt P450 in the liver cell endoplasmic reticulum ${ }^{20}$ leading to the generate an unstable complex of $\mathrm{CCl}_{3}$ radical. This trichloromethyl radical reacts rapidly with $\mathrm{O}_{2}$ to yield trichloromethyl peroxy radical, which is reported as a highly reactive species. Almost all parts of the plants were being used as a medicine to prevent and cure many diseases and for other purposes. ${ }^{21,22,23}$ Nowadays attention is being focused on herbal medicines because of their effectiveness, easily available, low cost and for being comparatively devoid of side effects. The present study was designed with an aim of assessing the hepatoprotective activity by the stem bark and leaf extract of Lawsonia inermis Linn. against $\mathrm{CCl}_{4}$ induced liver damage. Scavengers of free radicals can reduce side effects of these drugs. Plant kingdom possess several non-toxic compounds that can scavenge free radicals and boost the antioxidant defense mechanism in the body and have a protective and curative role against tissue damage induced by chemicals and drugs. ${ }^{24-29}$

\section{MATERIALS AND METHODS}

\section{Plant material}

The leaves of Lawsonia inermis were collected in and around Vellore District, Tamilnadu, and authenticated at the Department of Botany, C. Abdul Hakeem College, Melvisharam, Vellore Dt, Tamil Nadu. Voucher specimen was deposited at the Institutes' Herbarium.The collected fresh plants were washed thoroughly 2-3 times in running tap water and once again with sterile water and then stained it well and shade-dried at room temperature without any contamination. The dried stem bark and leaves were collected in separately and then powdered using a grinder.

\section{Plant extract preparation}

The shade dried plant materials were powdered (stem bark and leaf) separately in an electrical blender. The powdered material of the stem bark and leaf were extracted for 3 days with Soxhlet extraction by using methanol $(500 \mathrm{ml}$ for 100 gms) as solvent. The extracts was filtered and dried separately under reduced pressure on rotary evaporator to obtain $(10 \%)$ of each extract. The obtained powder was then subjected to phytochemical analysis to determine the chemical constituents present in the extract and the remaining was stored at $5^{\circ} \mathrm{C}$ for further use.

\section{Animals}

Wistar albino rats, male (175-200g) were obtained from the Institute's Animal House, C. Abdul Hakeem College, Melvisharam, Tamil Nadu, India. They were housed under standard conditions (temperature $25-27^{\circ} \mathrm{C}$, relative humidity $60-70 \%$ and $12 \mathrm{hr}$ dark-light cycles), fed with commercial rat feed (Lipton India Ltd., Mumbai, India) and boiled water ad libitum. In this study, experimental protocol and procedures employed were approved by the Animal Ethics Committee of C. Abdul Hakeem College, Melvisharam, Tamil Nadu, India (No.1011/c/06/CPCSEA). The rats were kept and monitored in animal house for ten days before starting the experiment.

\section{Experimental design}

Group I: Normal rats - Treated with common diet and water.

Group II: Rats injected $30 \% \mathrm{CCl}_{4}$ with olive oil ( $1 \mathrm{ml} / \mathrm{kg}$ body wt., by intra peritoneal administration) every 72 hrs for 3 successive doses.

Group III: The $\mathrm{CCl}_{4}$ injected rats were treated with silymarin (100 mg/kg b.wt.) orally by intra gastric tube for 30 days.

Group IV: The $\mathrm{CCl}_{4}$ injected rats were treated with methanol stem bark extract $(250 \mathrm{mg} / \mathrm{kg}$ b.wt.) of Lawsonia inermis Linn. orally, by intra gastric tube for 30 days.

Group V: The $\mathrm{CCl}_{4}$ injected rats were treated with methanol leaf extract ( $250 \mathrm{mg} / \mathrm{kg}$ b. wt.) of Lawsonia inermis Linn. orally, by intra gastric tube for 30 days.

The animals were sacrificed under the light ether anesthesia. Blood was drawn by cardiac puncture and serum samples were obtained by centrifuging all blood at $3000 \mathrm{rpm}$ and $4^{\circ} \mathrm{C}$. Hepatic tissue was homogenized in suitable buffer and centrifuged at $12,000 \mathrm{rpm}$ for $20 \mathrm{~min}$ at $4^{\circ} \mathrm{C}$. The supernatant was collected and stored at $-80^{\circ} \mathrm{C}$ for assay of the marker enzymes and antioxidant studies.

\section{Assessment of hepatoprotective activity}

Hepatic enzymes, AST and ALT were used as the biochemical markers of the hepatic cell damage and were assayed by the method of. ${ }^{30}$ ALP activity was measured using the method of ${ }^{31}$, and serum bilirubin was estimated by the method of ${ }^{32}$, to assess the acute hepatic damage caused by $\mathrm{CCl}_{4}$.

\section{Assay of superoxide dismutase activity (SOD)}

The activity of superoxide dismutase (SOD) was measured by the modified method of. ${ }^{33}$ The liver homogenate containing about $5 \mu \mathrm{g}$ of protein- was mixed with sodium pyrophosphate buffer, PMT and NBT. The reaction was initiated by the addition of $\mathrm{NADH}$. Then, the reaction mixture was incubated at $30^{\circ} \mathrm{C}$ for $90 \mathrm{~s}$. Next, the reaction was stopped by the addition of $1 \mathrm{ml}$ of glacial acetic acid. The absorbance of the resultant chromogen was measured at $560 \mathrm{~nm}$. One unit of SOD activity is defined as the enzyme concentration required to inhibit chromogen production by $50 \%$ in $1 \mathrm{~min}$ under the assay condition.

\section{Assay of Catalase (CAT)}

The CAT activity was measured in liver homogenates by the method of. ${ }^{34}$ For the assay, the liver homogenates containing $5 \mu \mathrm{g}$ total proteins were mixed separately with 
$700 \mu \mathrm{l}, 5 \mathrm{mM}$ hydrogen peroxide and incubated at $37^{\circ} \mathrm{C}$. The disappearance of peroxide was observed at $240 \mathrm{~nm}$ for $15 \mathrm{~min}$. One unit of catalase activity is that which reduces $1 \mu \mathrm{mol}$ of hydrogen peroxide per minute.

\section{Assay of Glutathione-S-transferase (GST)}

Glutathione-S-transferase activity was estimated by the method of. ${ }^{35}$ The reaction mixture consisted of $2.75 \mathrm{ml}$ sodium phosphate buffer $(0.1 \mathrm{M}, \mathrm{pH} 7.4), 0.1 \mathrm{ml}$ reduced glutathione $(1 \mathrm{mM}), 0.1 \mathrm{ml}$ PMS $(10 \% \mathrm{w}: \mathrm{v})$ in a volume of $3.0 \mathrm{ml}$. The changes in the absorbance were recorded at $340 \mathrm{~nm}$ and the activity of the enzymes was calculated as $\mathrm{nmol}$ CDNB conjugate formed/ $\mathrm{min} / \mathrm{mg}$ protein using a molar coefficient of 9.6_103:M:cm.

\section{Statistical analysis}

The obtained data were expressed as mean \pm standard deviation (SD) and analyzed using one-way analysis of variance (ANOVA), followed by Scheffe post hoc test. The data were analyzed with SPSS version 16 software (SPSS Inc., Chicago, USA). Statistical significance of difference was accepted at the $p$-values of less than 0.05 .

\section{RESULTS}

\section{Effect of Lawsonia inermis on $\mathrm{CCl}_{4}$-induced hepatotoxicity}

The results of $\mathrm{CCl}_{4}$-induced hepatotoxicity were summarised in Table $1 . \mathrm{CCl}_{4}$-treated group revealed a significant elevation of serum marker enzyme activities of ALT (98.90\%), AST (78.38\%), ALP (83.24\%) and bilirubin (83.58\%) as compared to normal control ( $p<0.05)$, which indicates that $\mathrm{CCl}_{4}$ induced damage to the hepatic cells. However, treatment with Lawsonia inermis stem bark at a dose of $250 \mathrm{mg} / \mathrm{kg}$ had significantly decreased the elevated percentages of ALT, AST, and ALP and bilirubin by $43.63 \%$, $40.76 \%, 41.27 \%$, and $39.83 \%$ respectively as compared with $\mathrm{CCl}_{4}$ treated group. Similarly, methanol leaf extract of Lawsonia inermis at a dose of $250 \mathrm{mg} / \mathrm{kg}$ had significantly decreased the elevated percentages of ALT, AST, and ALP and bilirubin by $41.41 \%, 38.34 \%, 40.00 \%$, and $35.77 \%$ respectively when compared with $\mathrm{CCl}_{4}$ treated group. Positive control drug, silymarin, at dose of $100 \mathrm{mg} / \mathrm{kg}$ also reduced the levels of serum ALT, AST, and ALP and bilirubin (47.53\%, 42.33\%, $43.41 \%$ and $41.46 \%)$ respectively (Table.1).

\section{Effect of Lawsonia inermis on hepatic antioxidant enzyme activities}

The natural antioxidant enzymes are the defense system of the body. The level of the antioxidants (SOD, catalase, GST and GPx) exhibits the real scenario of the body. The activities of liver SOD, catalase, GPx and GST in $\mathrm{CCl}_{4}$ treated group were significantly decreased by $51.45 \%, 47.76 \%$, $53.06 \%$, and $41.34 \%$ respectively, when compared with the normal control group. Methanol extract of Lawsonia inermis stem bark showed a significant enhancement in the activities of SOD, CAT, GPx and GST to $94.87 \%, 77.62 \%$, $106.94 \%$, and $57.46 \%$ respectively compared to the $\mathrm{CCl}_{4}$ treated group. Similarly administration of the methanol leaf extract of Lawsonia inermis showed a hike in the levels of the SOD, catalase, GPx and GST (71.79\%, 73.99\%, $100.21 \%$ and $47.61 \%$ ) reduced by the $\mathrm{CCl}_{4}$. Administration of silymarin also significantly increased $(p<0.05)$ the activities of SOD, CAT, GPx and GST (100.85\%, $86.27 \%$, $110.73 \%$, and $62.53 \%$ ) respectively reduced by the $\mathrm{CCl}_{4}$ compared to the $\mathrm{CCl}_{4}$-treated group (Table 1 ).
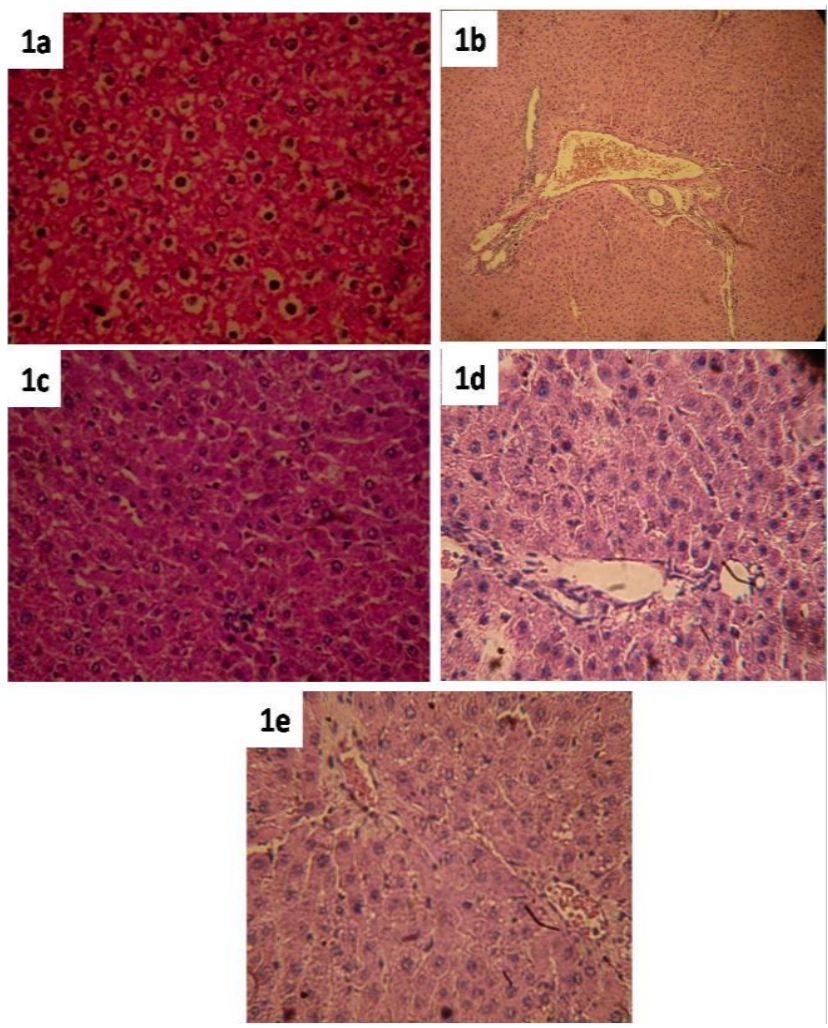

Figure 1: Histopathological changes in liver tissues stained with $\mathrm{H} \& \mathrm{E}$.

$1 \mathrm{a}-$ Normal, $1 \mathrm{~b}-\mathrm{CCl}_{4}$ induced cell, $1 \mathrm{c}-\mathrm{CCl}_{4}+$ Sylimarin treated cell, $1 \mathrm{~d}-\mathrm{CCl}_{4}+250 \mathrm{mg} / \mathrm{kg}$ body wt., $\mathrm{Li}$ bark extract treated, $1 \mathrm{e}$ $\mathrm{CCl}_{4}+250 \mathrm{mg} / \mathrm{kg}$ body wt., $\mathrm{Li}$ leaf extract treated

\section{Histological examinations}

Histological studies also provided a supporting evidence for the biochemical analysis. In normal control animals, liver sections showed normal hepatic cell architecture with well preserved cytoplasm, prominent nucleus and nucleolus and central vein (Fig. 1a). The leaves extract treated rats revealed moderate inflammatory cell infiltration of hepatocytes, moderate necrosis, mild ballooning, degeneration, and mild fibrosis (Fig. 1e), compared with the lesions observed in the $\mathrm{CCl}_{4}$ control group (Fig. 1b). The lesions of silymarin treated rats showed traces of mild diffused necrosis of hepatocytes, mild inflammatory cell infiltration, trace of ballooning degeneration, and mild fibrosis (Fig. 1c). On the other hand, a trace of mild degree of hepatocellular necrosis, inflammatory cell and hepatocyte fibrosis, and mild degree of balooning, degeneration were observed in the liver of extracts of Lawsonia inermis stem bark ( $250 \mathrm{mg} / \mathrm{kg}$ b.wt.) treated rats (Fig. 1d). Fig.1e. shows a nearly normal cell, which was treated with leaf extract of $L i$. 
Table 1: Effect of bark and leaf extract on $\mathrm{CCl}_{4}$ induced hepatotoxicity: Levels of ALT, AST, ALP, BR, SOD, CAT, GPX, and GST

\begin{tabular}{|c|c|c|c|c|c|c|c|c|}
\hline \multirow[t]{2}{*}{ Groups } & \multicolumn{4}{|c|}{ Parameters in the serum } & \multicolumn{4}{|c|}{ Parameters in liver tissue } \\
\hline & $\begin{array}{l}\quad \text { ALT } \\
(\mathrm{IU} / \mathrm{I} / \mathrm{min} / \mathrm{mg} \\
\text { protein) }\end{array}$ & $\begin{array}{c}\text { AST } \\
\text { (IU/I } / \mathrm{min} / \mathrm{mg} \\
\text { protein) }\end{array}$ & $\begin{array}{c}\text { ALP } \\
\text { (IU/I/min } / \mathrm{mg} \\
\text { protein) }\end{array}$ & $\begin{array}{c}\text { Bilirubin } \\
\text { (mg/dl) }\end{array}$ & $\begin{array}{l}\text { SOD } \\
\left(U_{1} / \mathrm{mg}\right. \\
\text { protein) }\end{array}$ & $\begin{array}{c}\text { CAT } \\
\left(\mathrm{U}_{2} / \mathrm{mg} \text { protein }\right)\end{array}$ & $\begin{array}{c}\text { GPx } \\
\left(\mathrm{U}_{3} / \mathrm{mg} \text { protein }\right)\end{array}$ & $\begin{array}{c}\text { GST } \\
\left(\mathrm{U}_{4} / \mathrm{mg} \text { protein }\right)\end{array}$ \\
\hline $\begin{array}{l}\text { Group-I } \\
\text { (Normal) }\end{array}$ & $52.15 \pm 1.51$ & $69.22 \pm 0.98$ & $77.35 \pm 1.32$ & $0.67 \pm 0.26$ & $2.41 \pm 1.14$ & $80.33 \pm 0.94$ & $10.12 \pm 1.06$ & $5.37 \pm 0.42$ \\
\hline $\begin{array}{c}\text { Group-II } \\
\left(\mathrm{CCl}_{4} \text { control }\right)\end{array}$ & $103.73 \pm 1.15^{a}$ & $123.48 \pm 1.96^{a}$ & $141.74 \pm 1.11^{\mathrm{a}}$ & $1.23 \pm 0.75^{\mathrm{a}}$ & $1.17 \pm 1.12^{\mathrm{a}}$ & $41.96 \pm 1.41^{\mathrm{a}}$ & $4.75 \pm 1.15^{\mathrm{a}}$ & $3.15 \pm 1.02^{\mathrm{a}}$ \\
\hline$\%$ of change (Normal vs $\mathrm{CCl}_{4}$ ) & +98.90 & +78.38 & +83.24 & +83.58 & -51.45 & -47.76 & -53.06 & -41.34 \\
\hline $\begin{array}{c}\text { Group-III }\left(\mathrm{CCl}_{4}+\right. \\
\text { Silymarin } 100 \mathrm{mg} / \mathrm{kg} \text { body } \\
\text { wt., })\end{array}$ & $54.42 \pm 1.27^{b}$ & $71.21 \pm 1.04^{b}$ & $80.21 \pm 0.75^{b}$ & $0.72 \pm 0.48^{b}$ & $2.35 \pm 1.07^{b}$ & $78.16 \pm 1.11^{b}$ & $10.01 \pm 1.24^{b}$ & $5.12 \pm 0.54^{b}$ \\
\hline $\begin{array}{c}\% \text { of change }\left(\mathrm{CCl}_{4}+\mathrm{vs}\right. \\
\text { silymarin })\end{array}$ & -47.53 & -42.33 & -43.41 & -41.46 & +100.85 & +86.27 & +110.73 & +62.53 \\
\hline $\begin{array}{c}\text { Group -IV } \\
\mathrm{CCl}_{4}+\mathrm{Li} \text { (bark } 250 \mathrm{mg} / \mathrm{kg} \text { body } \\
\text { wt.,) }\end{array}$ & $58.47 \pm 1.03^{b}$ & $73.14 \pm 1.05^{b}$ & $83.24 \pm 1.44^{b}$ & $0.74 \pm 0.68^{b}$ & $2.28 \pm 1.16^{\mathrm{b}}$ & $74.53 \pm 1.25^{b}$ & $9.83 \pm 1.55^{b}$ & $4.96 \pm 1.21^{b}$ \\
\hline $\begin{array}{l}\% \text { of Changes } \\
\mathrm{CCl}_{4} \text { vs } L i \text { (bark) }\end{array}$ & -43.63 & -40.76 & -41.27 & -39.83 & +94.87 & +77.62 & +106.94 & +57.46 \\
\hline $\begin{array}{c}\text { Group }-\mathrm{V} \\
\mathrm{CCl}_{4}+\mathrm{Li} \text { (leaf } 250 \mathrm{mg} / \mathrm{kg} \text { body } \\
\text { wt.,) }\end{array}$ & $60.77 \pm 1.13^{b}$ & $76.13 \pm 1.21^{b}$ & $85.03 \pm 1.30^{b}$ & $0.79 \pm 0.87^{b}$ & $2.01 \pm 1.53^{b}$ & $73.01 \pm 1.23^{b}$ & $9.51 \pm 0.41^{b}$ & $4.65 \pm 0.16^{b}$ \\
\hline $\begin{array}{l}\% \text { of Changes } \\
\mathrm{CCl}_{4} \text { vs } L i \text { (leaf) }\end{array}$ & -41.41 & -38.34 & -40.00 & -35.77 & +71.79 & +73.99 & +100.21 & +47.61 \\
\hline
\end{tabular}

1.Values are mean of six individual observations in each group \pm S.D.

2. ' $P$ ' denotes statistical significance. $P<0.05$. ' + ' and '-'indicates \% of changes over the $\mathrm{CCl}_{4}$ intoxicated groups. a- compared with normal, b-compared with $\mathrm{CCl} 4$.

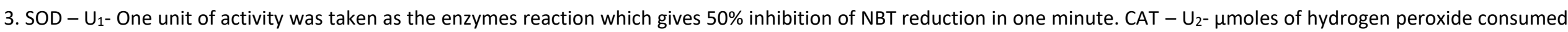
per minute. GPx - $\mathrm{U}_{3}-\mu \mathrm{g}$ of glutathione consumed per minute. GST - $\mathrm{U}_{4}-\mu$ moles of CDNB - GSH conjugate formed per minute. 


\section{DISCUSSION}

Carbon tetrachloride is a xenobiotic that produces hepatotoxicity in experimental animals and human beings and its biotransformed metabolites (by Cytochrome P-450 (CYP)) such as trichloromethyl radical $\left(\mathrm{CCl}_{3}\right)$ and trichloromethyl peroxyl radical $\left(\mathrm{CCl}_{3} \mathrm{O}_{2}\right)$ were reported to initiate peroxidation ${ }^{20}$ and is involved in the pathogenesis of liver. ${ }^{36}$ Both free radicals were capable of binding to proteins and lipids, leading to membrane lipid peroxidation and finally cell necrosis. ${ }^{37-20}$ Many studies have shown that a crucial mechanism of the hepatoprotective effects may be related to the ability of antioxidants to scavenge reactive oxygen species. ${ }^{38}$

In the present study, we found that treatment with the Lawsonia inermis significantly inhibited $\mathrm{CCl}_{4}$-induced liver damage as evidenced by decreased serum activities of AST, ALT, and ALP, and bilirubin. To prevent the oxidative damage, tissues have constructed an antioxidant defense system that includes enzymatic antioxidants and nonenzymatic antioxidants. ${ }^{39-40}$ Therefore, the activities of enzymatic antioxidants inhibit the generation of free radicals. Hence the hepatic cells are protected from $\mathrm{CCl}_{4}$ induced liver damage. ${ }^{41}$ SOD is a manganese containing enzyme in mitochondria which converts the dismutation of superoxide anions into hydrogen peroxide $\left(\mathrm{H}_{2} \mathrm{O}_{2}\right)$. ${ }^{42}$ Catalase is a hemoprotein in all aerobic cells that decomposes $\mathrm{H}_{2} \mathrm{O}_{2}$ to oxygen and water. GSH and GPx metabolize $\mathrm{H}_{2} \mathrm{O}_{2}$ and hydroperoxides to non-toxic products and terminate the chain reaction of lipid peroxidation by removing lipid hydroperoxides from the cell membrane. ${ }^{43}$ GSH-Rd is a cytosolic hepatic enzyme involved in the detoxification of a range of xenobiotic compounds by their conjugation with GSH. ${ }^{44,45,46}$ These antioxidant enzymes are effortlessly inactivated by lipid peroxides or free radicals, which results in decreased activities of these enzymes in $\mathrm{CCl}_{4}$ toxicity. The results of the present study indicate that SOD, catalase GPx and GST activities were significantly decreased in $\mathrm{CCl}_{4}$ treated liver, compared with normal control rats, implying increased oxidative damage to the liver. On the contrary, SOD, catalase, GPx and GST levels were significantly elevated by administration of Lawsonia inermis and sylimarine in $\mathrm{CCl}_{4}$-induced rats, suggesting that it has the ability to restore/ maintain the activity of hepatic enzymes in $\mathrm{CCl}_{4}$-damaged liver.

Histopathological observations such as hepatocyte necrosis, inflammatory cell infiltration, ballooning degeneration, and hepatocyte fibrosis were recorded. Through semi-quantitative assessment, all scores of histopathologic examinations in the $\mathrm{CCl}_{4}$-treated group were significantly higher than that of the normal control $(p<$ 0.05 ), indicating that $\mathrm{CCl}_{4}$ has induced severe damage to the hepatic cells. The extract of stem bark and leaf extracts of Lawsonia inermis significantly decreased $(p<0.05)$ the scores of hepatocyte necrosis and inflammatory cell infiltration as compared to $\mathrm{CCl}_{4}$-treated group. Similar cell architecture was observed in animals treated with silymarin when compared to normal. Microscopic examinations confirmed that severe liver damages induced by $\mathrm{CCl}_{4}$ were remarkably reduced by the administration of methanol extract of stem bark and leaf, which was in good correlation with the results of the serum aminotransferase and hepatic antioxidant enzyme activities. According to the results obtained, it may be concluded that all the fractions of the methanol extract of the Lawsonia inermis (stem bark and leaf) proved to have strong antioxidant activity, reducing power. ability, and free radical scavenging activity. Among these two extracts, extract of bark revealed significant curative effect than extract of leaves.

\section{CONCLUSION}

The methanol extract of Lawsonia inermis (stem bark and leaf) exhibits hepatoprotective and curative effects on $\mathrm{CCl}_{4}$ induced liver damages. Treatment with $250 \mathrm{mg} / \mathrm{kg}$ of Lawsonia inermis (stem bark and leaf) exhibited optimal protection on the $\mathrm{CCl}_{4}$ induced hepatotoxicity and nearly similar hepatoprotective and curative effects like silymarin. Lawsonia inermis contains several chemical compounds like alkaloids, saponins, titerpenoid etc. These might be responsible for the hepatoprotective and curative activity in the $\mathrm{CCl}_{4}$ induced rats.

\section{REFERENCES}

1. Chrungoo VJ, Singh K, Singh J. Differential biochemical response of freshly isolated rat hepatocytes to paracetamol, carbon tetrochloride and D galactosamine toxicity. Indian J Exp Biol. 1997; 35: 603610.

2. Ujah OF, Ujah IR, Johnson JT, Ekam VS, Udenze EC. Hepatoprotective property of ethanolic leaf extract of Moringa oleifera on carbon tetrachloride $\left(\mathrm{CCl}_{4}\right)$ induced hepatotoxicity. Scholars Research Library. 2013; 3(2):15-22.

3. Jayavelu A, Natarajan A, Sundaresan S, Devi K, Senthil kumar B. Hepatoprotective Activity of Boerhavia Diffusa Linn. (Nyctaginaceae) against Ibuprofen Induced Hepatotoxicity in Wistar albino rats. Inter J of Pharma Research and Review. 2013; 2(4): 1-8.

4. Savita Mishra, Vidhu Aeri, Deepshikha Pande Katare. Hepatoprotective medication for liver injury. World J of Pharmacy and Pharmaceutical Sciences. 2014; 3(5): 142.

5. Cowan MM. Plant Products as antimicrobial agents. Clinical Microbiology Review. 2009; 12(4): 564-582.

6. Maliik B, Stillman M. Chemotherapy-induced peripheral neuropathy. Curr Neurol Neurosci Rep. 2008; 8: 56-65.

7. Susi E, Ashma, Taufiq Y. Comparing of the cytotoxicities properties \& mechanism of Lawsonia inermis and Strobilanthes extract against several cancer cell lines. J Med Sci. 2007; 7: 1098-1102.

8. Jain SK. Medicinal Plants. National Book Trust, India. 1973; 91. 
9. Singh S, Srivastava NM, Modi NT, Saifi AQ. Antiinflammatory activity of Lawsonia inermis. Curr Sci. 1982; 51: 470 .

10. Ali BH, Bashir AK, Tanira MO. Anti-inflammatory, antipyretic, and analgesic effects of Lawsonia inermis L. (henna) in rats. Pharmacology. 1995; 51; 356-63.

11. Dymock W, Warden CJH, Hopper D. Pharmacographica Indica, Periodical Experts, Delhi, 1976; 41-43.

12. Shivananda Nayak B, Godwin Isitor, Davis EM, Pillai GK. The Evidence based wound healing activity of Lawsonia inermis L. Phytother Res. 2007; 21: 827-831.

13. Gagandeep Chaudhary, Sandeep Goyal, Priyanka Poonia. Lawsonia inermis Linnaeus: A Phytopharmacological Review. In J of Pharmaceu Sciences and Drug Res. 2010; 2(2): 91-98.

14. Satyavati GV, Gupta A, Tandon N. Medicinal Plants of India, vol. 2. Indian Council for Medical Research, New Delhi, India. 1987; 138.

15. Abdul Moneim MA. Evaluation of Lawsonia inermis Linn. (Sudanese Henna) leaf extracts as an antimicrobial agent. Res J of Biol Sci. 2007; 2: 419-423.

16. Dixit SN, Srivastava HS, Tripathi RD. Lawsone, the antifungal antibiotic from the leaves of Lawsonia inermis and some aspects of its mode of action. Indian Phytopathol. 1980; 31: 131-133.

17. Nadkarni KM, Nadkarni AK. Indian Materia Medica with Ayurvedic, Unani Tibbi, Siddha, Allopathic, Homeopathic, Naturopathic and Home Remedies, Vol. 2. Popular Prakashan Private Ltd., Bombay, India, ISBN no.81-7154-143-7. 1999.

18. Prasad V, Gupta SC. Inhibitory effect of bark and leaf decoctions on the activity of peptic enzymes of Alternaria tenuis. Indian J Exp Biol. 1967; 5: 192-193.

19. Anand KK, Singh B, Chand D, Chandan BK. An evaluation of Lawsonia alba extract as hepatoprotective agent. Planta Med. 1992; 58: 23-25.

20. Recknagel RO, Glende EA, Dolak JA, Walter RL. Mechanism of carbon tetrachloride toxicity. Pharmacol Ther. 1989; 43:139-154.

21. Venkat Raji Reddy G, Vijay Kumar R, Krishna Reddy M. Hepatoprotective activity of Elytraria acaulis plant extracts in albino rats. In J of Pharmaco and Phytochemi Res. 2015; 6(4): 925 - 929.

22. Jaya Sankar Reddy V, Deval Rao G, Mallikajuna K. A review on hepatoprotective activity of some medicinal plants. In J of Inno Pharmace Res. 2014; 5(2): 395-404.

23. Himajan, Neelufar shama S. Herbal wealth for hepatotoxicity: a review. Asian J of Pharmace and Clini Res. 2015; 8(1): 3-9.

24. Rege NN, Thatte UM, Dahanukar SA. Adaptogenic properties of six rasayana herbs used in ayurvedic medicine. Phytother Res. 1999; 13: 275-91.
25. Jose JK, Kuttan R. Hepatoprotective activity of Emblica officinalis and Chyavanaprash. J Ethnopharmacol. 2000; 72: 135-140.

26. Kumar $\mathrm{KBH}$, Kuttan R. Chemoprotective activity of an extract of Phyllanthus amarus against cyclophosphamide induced toxicity in mice. Phyto Med. 2005; 12: 494-500.

27. Stahl W, Sies H. Carotenoiods and flavanoids contribute to nutritional protection against skin damage from sunlight. Mol Biotechnol. 2007; 37: 26-30.

28. Jayavelu A, Natarajan A, Sundaresan S, Devi K, Senthil Kumar B. Therapeutic Efficacy of combined plant extract of Andrographis panicultata Wall. ex Nees and Achyranthes aspera L. against pracetamol induced hepato and renal toxicity in wistar albino rats. Int J Applied Bio Research. 2013; 16: 8-16.

29. Gunturu Abhilash, Uma Maheswari Y, Avinash Gopal J, Dilip Chanda. Review on some medicinal plants with hepato-protective activities. J of Pharmaco and Phytochem. 2014; 2(2): 10-21.

30. Retiman S, Frankel AS. A colorimetric method for the determination of serum glutamine oxaloacetic and glutamic pyruvic transaminases. Am J Clin Pathol. 1957; 28: 53-56.

31. King J. In Practical Clinical Enzymology D Von Nostrand Co. Ltd., London. 1965; 182.

32. Mally E, Evelyn K. The determination of bilirubin with the photoelectric colorimeter. J Biol Chem. 1937; 199: 481- 485.

33. Kakkar P, Das B, Viswanathan PN. A modified spectrophotometric assay of superoxide dismutase. In $\mathrm{J}$ of Biochem and Biophysics. 1984; 21: 130-132.

34. Bonaventura J, Schroeder WA, Fang S. Human erythrocyte catalase: an improved method of isolation and a reevaluation of reported properties. Archives of Biochem and Biophysics. 1972; 150: 606-617.

35. Habig WH, Pabst MJ, Jokoby WB. Glutathione-Stransferase: the first enzymatic step in mercapturic acid formation. J Biol Chem. 1974; 249: 7130-7139.

36. Recknagel RO. Carbon tetrachloride hepatotoxicity. Pharmacol Rev. 1967; 19: 145-208.

37. Brattin WJ, Glende Jr EA, Recknagel RO. Pathological mechanisms in carbon tetrachloride hepatotoxicity. J Free Radic Biol Med. 1985; 1: 27-38.

38. Kodai $S$, Takemura $S$, Minamiyama $Y$, Hai $S$, Yamamoto S, Kubo S, Yoshida Y, Niki E, Okada S, Hirohashi K, Suehiro S, S-Allyl. Cysteine prevents $\mathrm{CCl}_{4}$ - induced acute liver injury in rats. Free Radic Res. 2007; 41: 489497.

39. Halliwell B, Gutteridge JMC. Role of free radicals and catalytic metal irons in human disease: an overview. Methods in Enzymology. 1990; 186: 59-85.

40. Wang BJ, Liu CT, Tseng CY, Wu CP, Yu ZR. Hepatoprotective and antioxidant effects of Bupleurum 
kaoi extract and its fractions fractionated using supercritical $\mathrm{CO}_{2}$ on $\mathrm{CCl}_{4}$-induced liver damage. Food Chem Toxicol. 2004; 42: 609-617.

41. Campo GM, Squadrito F, Ceccarelli S, Calo M, Avenoso A, Campo S, Squadrito G, Altavilla D. Reduction of carbon tetrachloride-induced rat liver injury by IRFI 042, a novel dual vitamin E-like antioxidant. Free Radic Res. 2001; 34: 379-393.

42. Reiter RJ, Tan D, Osuna C, Gitto E. Actions of melatonin in the reduction of oxidative stress. J of Biomedical Science. 2000; 7: 444-458.

43. Jung K, Henke W. Developmental changes of antioxidant enzymes activity in kidney and liver from rats. Free Radic Biol Med 1996; 20: 613-617.
44. Baudrimont I, Ahouandjivo R, Creppy EE. Prevention of lipid peroxidation induced by ochratoxin-A in Vitro cells in culture by several agents. Chemico-Biol Interactions. 1997; 104: 29-40.

45. Naik SR, Panda VS. Antioxidant and hepatoprotective effects of Ginkgo biloba phytosomes in carbon tetrachloride-induced liver injury in rodents. Liver Int. 2007; 27: 393-399.

46. Natarajan A, Jayavelu A, Thangamani R, Devi K, Senthil Kumar B. Protective potential of ethanol extract of Annona squamosa against cisplatin induced hepatorenal toxicity in albino rats. Life Science Archives (LSA). 2015; 1(5):322-328.

Source of Support: The author(s) received no financial support for the research, authorship, and/or publication of this article.

Conflict of Interest: The author(s) declared no potential conflicts of interest with respect to the research, authorship, and/or publication of this article.

For any question relates to this article, please reach us at: editor@globalresearchonline.net New manuscripts for publication can be submitted at: submit@globalresearchonline.net and submit_ijpsrr@rediffmail.com 